\title{
PENINGKATAN HASIL BELAJAR MATEMATIKA SISWA SD DENGAN MENGGUNAKAN MODEL PEMBELAJARAN PROBLEM BASED LEARNING (PBL)
}

\author{
Fatmawati $^{1 *}$, Etna Syafweny ${ }^{2}$, Susilawaty $^{3}$, Hanifatul Rahmi $^{4}$ \\ ${ }^{1}$ SDN 001 Rimba Sekampung, Dumai \\ ${ }^{2}$ SDN 012 Purnama, Dumai \\ ${ }^{3}$ SDN 004 Mundam, Dumai \\ ${ }^{4}$ Sekolah Tinggi Teknik (STT) Dumai \\ *fatmawati121366@gmail.com
}

\begin{abstract}
This article was a classroom action research that contains two cycles that was located at State Elemnetary School 001 Rimba Sekampung in the third grade with 20 students. The object of this study was student's mathematical learning outcome in multiplication and divition subjects with the learning steps were planning, action, observation and reflection. The instruments that we used were the learning outcome tests and observation that were analyzed quantitatively and qualitatively. According to the data analysis results found that: (1) the average of student's learning outcome at cycle I was 80 with percentage of student completeness was 71,43\%; (2) the average of student's learning outcome at cycle II increased in 83,30 with percentage of student completeness was $80,95 \%$; (3) the observation result at cycle I was 82,50 with good category, increased in 92,50 with good category at cycle II. The conclusion was Problem Based Learning Model can improve student's learning outcome.
\end{abstract}

Key Words: problem based learning; learning outcone; classroom action research; cycles.

\begin{abstract}
Abstrak: Artikel ini merupakan penelitian tindakan kelas yang terdiri atas dua siklus yang dilaksanakan pada SD Negeri 001 Rimba Sekampung di Kelas III yang berjumlah 20 orang siswa. Objek penelitian ini adalah hasil belajar matematika siswa pada materi perkalian dan pembagian dengan tahapan perencanaan, tindakan, pengamatan, dan refleksi. Instrumen yang digunakan adalah tes hasil belajar dan observasi yang dianalisis secara kuantitatif dan kualitatif. Berdasarkan hasil analisis data diperoleh bahwa: (1) rata-rata hasil belajar siswa pada siklus I adalah 80 dengan persentase ketuntasan siswa 71,43\%; (2) rata-rata hasil belajar siswa pada siklus II meningkat menjadi 83,30 dengan persentase ketuntasan siswa 80,95\%; dan (3) hasil obeservasi pada siklus I sebesar 82,50 dengan kategori baik mengalami peningkatan menjadi 92,50 dengan kategori sangat baik pada siklus II. Kesimpulannya adalah model pembelajaran Problem Based Learning (PBL) dapat meningkatkan hasil belajar siswa.
\end{abstract}

Kata Kunci: problem based learning; hasil belajar; penelitian tindakan kelas; siklus. 


\section{PENDAHULUAN}

Matematika merupakan salah satu mata pelajaran yang selalu ada di setiap tingkat pendidikan mulai dari jenjang sekolah dasar hingga ke jenjang perguruan tinggi. Belajar matematika merupakan syarat cukup yang harus dipenuhi untuk melanjutkan pendidikan ke tingkat berikutnya sebab melalui pembelajaran matematika, siswa akan belajar bernalar, berpikir kritis, kreatif serta aktif. Guru seharusnya mampu memfasilitasi dan menciptakan proses belajar-mengajar yang menyenangkan sebab akan memberikan pengaruh terhadap pencapaian hasil belajar siswa. Salah satu tujuan dari model pembelajaran matematika adalah untuk melatih siswa agar mampu berpikir dalam menghadapi masaah matematis dalam kehidupan sehari-hari.

Matematika merupakan salah satu ilmu pasti yang mencakup ide-ide abstrak yang terdiri dari bilanganbilangan dan simbol-simbol operasi hitung melalui aktivitas berhitung serta mampu meningkatkan kemampuan berpikir dan berpendapat dalam memecahkan permasalahan matematis yang berkaitan dengan kehidupan sehari-hari. Hampir seluruh aktivitas manusia berkaitan dengan matematika. Misalnya kegiatan jual-beli barang pada bidang ekonomi yang menggunakan perhitungan matematis sebagai penentu harga.

Namun faktanya bidang studi matematika di tingkat sekolah dasar saat sekarang ini bukan merupakan bidang studi yang diminati siswa. Siswa menganggap matematika merupakan bidang studi yang menumbuhkan kecemasan siswa sebab matematika sulit untuk dipahami dan dimengerti serta sangat membosankan. Guru terbiasa mengajar dengan menggunakan metode ceramah sehingga siswa mudah jenuh dalam mengikuti proses belajar-mengajar. Siswa juga tidak diberikan situasi nyata dalam kehidupan sehari-hari sehingga mereka tidak merasa matematika sangat penting untuk dipelajari. Jika situasi yang seperti ini dibiarkan berkelanjutan maka tentu saja akan memberikan dampak negatif terhadap hasil belajar siswa.

Pembelajaran di Sekolah Dasar diwarnai dengan perbedaan karakter dan gaya belajar siswa (Rahmi, Saputra, Desriati \& Fatmawat, 2020). Hasil observasi pada SD Negeri 001 Rimba Sekampung, peneliti melaksanakan tugas mengajar seperti biasanya pada materi perkalian dan pembagian. Dalam pelaksanaan proses pembelajaran hari tersebut berjalan lancar. pada kegiatan awal pembelajaran guru dan siswa berdoa bersama-sama, guru mengecek kehadiaran siswa, guru menyampaikan apresepsi memberikan motivasi kepada siswa dan menyampaikan bahwa materi pembelajaran pada pertemuan itu adalah perkalian dan pembagian. Tampak semua siswa masih berfokus kepada guru.

Selanjutnya guru menyampaikan tujuan dan materi pembelajaran pada pertemuan tersebut. Guru menerapkan metode tanya-jawab, tetapi terdapat siswa yang sudah mulai sibuk sendiri. Misalnya siswa mengobrol dengan 
teman sebangku. Setelah bertanya jawab, guru menjelaskan dan memberi contoh mengenai materi pembelajaran. Beberapa orang siswa tampak semangat tetapi selama kegiatan inti guru terbiasa menerapkan metode ceramah dan tanya-jawab melalui buku cetak. Guru memberikan kesempatan kepada siswa untuk bertanya jika masih terdapat materi yang belum dipahami. Namun tidak ada siswa yang memberikan pertanyaan kepada guru sehingga guru melanjutkan kegiatan pembelajaran dengan memberikan tugas mengenai materi pembelajaran tersebut.

SD Negeri 001 Rimba Sekampung memiliki KKM (Kriteria Ketuntasan Minimal) untuk pelajaran matematika adalah 70. Berdasarkan hasil pembelajaran siswa terlihat bahwa hasil dari penilaian tersebut hanya 13 siswa atau 66,7 \% siswa yang tuntas dari jumlah siswa keseluruhannya yaitu 21 siswa. Perolehan hasil tersebut menjelasakan bahwa hasil pembelajaran yaitu ketercapaian kompetensi yang tertuang dalam skenario pembelajaran dan tuntasnya individu masih dibawah KKM klasikal yaitu $75 \%$. Pencapaian suatu proses pembelajaran dikatakan berhasil apabila hasil ketuntasan pembelajaran diatas KKM (Nasution \& Lubis, 2019).

Berdasarkan hasil observasi awal penulis, proses belajar-mengajar belum berjalan secara efektif. Pembelajaran masih berpusat pada guru yang merupakan salah satu faktor penyebab rendahnya hasil belajar siswa. Penulis menyadari proses belajar-mengajar sebaiknya berpusat pada siswa sementara guru hanya berperan sebagai fasilitator. Siswa kelas III yang merupakan peralihan dari kelas II masih sulit dalam menyelesaikan soal cerita terutama dalam mengubah soal cerita ke dalam bentuk matematis. Selain penggunaan metode pembelajaran yang belum terlalu optimal, karakteristik siswa adalah tidak berminat dalam belajar matemtika sehingga selama proses pembelajaran, banyak siswa yang cenderung mengerjakan kegiatan lain, seperti bermain sendiri. Siswa cenderung sebagai pendengar lalu mencatat tulisan guru di papan tulis. Hal ini mengindikasikan siswa tidak begitu tertarik dalam pembelajaran matematika. Keadaan siswa yang tidak memiliki atensi terhadap proses pembelajaran diduga akan mengalami keterlambatan dalam belajar sehingga mengakibatkan rendahnya hasil belajar siswa.

Dari hasil data awal dapat disimpulkan bahwa hasil belajar siswa masih tergolong rendah. Rendahnya hasil belajar siswa dapat dipengaruhi oleh model pembelajaran yang digunakan guru. Karena itu peneliti ingin mengevaluasi, mengkaji dan menganalisis lebih lanjut untuk melakukan perbaikan agar mengalami peningkatan yang lebih baik baik pada proses pembelajaran maupun hasil belajar siswa. Tujuannya adalah mengetahui penyebab belum berhasilnya evaluasi dari pembelajaran matematika pada siswa kelas III SDN 001 Rimba Sekampung.

Upaya untuk perbaikan dan peningkatan hasil pembelajaran 
tersebut adalah dengan penerapan model pembelajaran. Salah satu model pembelajaran inovatif yang mendorong siswa dalam pemahaman materi dan peningkatan hasil belajarnya adalah model Problem Based Learning (PBL) yang berfokus kepada permasalahan di dalam kehidupan sehari-hari. Melalui model ini, siswa terlatih dalam menghadapi dan menyelesaikan permasalahan matematis dalam kehidupan, serta mampu untuk menumbuhkembangkan kemampuan berpikirnya. Siswa belajar menjadi penyidik yang aktif sehingga memicu kemampuan berpikir dan bernalar siswa dalam menyelesaikan permasalahan sehingga model ini dapat mengurangi kesulitan siswa saat belajar matematika (Nasution, Gunawan \& Yulia, 2019). Jadi, model PBL diharapakan dapat meningkatkan hasil belajar siswa.

Guru harus peka terhadap prestasi belajar siswa (Rahmi, Zamista $\&$ Saputra, 2019). Siswa dituntun untuk lebih mandiri dan terampil saat menggali informasi terkait materi yang sedang dipelajari. Siswa dituntut untuk menilai tingkat pemahamannya sendiri terkait materi pelajaran dengan cara metode tanya-jawab bersama temannya. Model PBL ini diduga mampu menumbuh kembangkan keterampilan berpikir tingkat tinggi (Siregar \& Nasution, 2019), penemuan, kemandirian belajar serta tingkat kepercayaan diri siswa.

\section{TINJAUAN TEORETIS}

Hasil belajar adalah perubahan tingkah laku siswa sesudah melalui proses pembelajaran. Tingkah laku sebagai hasil belajar meliputi ranah kognitif, afektif, dan psikomotorik (Majid, 2014). Hasil belajar pada ranah kognitif berkaitan dengan penguasaan materi sesuai dengan tujuan belajar.

Andersond dan Krathwohl (dalam Rusmono, 2012) menyatakan bahwa aspek kognitif pada taksonomi Bloom telah direvisi ke dalam dua dimensi yaitu proses kognitif dan dimensi pengetahuan. Dimensi proses kognitif terdiri dari 6 tingkatan: (1) ingatan, (2) pemahaman, (3) aplikasi, (4) analisis, (5) evaluasi dan (6) kreasi. Dimensi pengetahuan terdiri atas 4 tingkatan, yaitu (1) faktual, (2) konseptual, (3) prosedural, dan (4) metakognitif. Kemudian menurut Snelbeker (dalam Rusmono, 2012) perubahan dan kemampuan baru akan diperoleh siswa setelah proses pembelajaran berlangsung.

Dari pendapat para ahli di atas ditarik kesimpulan yaitu hasil belajar merupakan perubahan tingkah laku dan perolehan kemampuan baru setelah terlaksananya proses pembelajaran. Pada penelitian ini, penulis berfokus pada ranah kognitif.

Menurut Susanto (2013), hasil belajar siswa dipengaruhi oleh siswa itu sendiri yang meliputi kemampuan berpikir, tingkah laku, motivasi, minat, dan kesiapan siswa baik jasmani maupun rohani. Kedua dipengaruhi oleh lingkungan yang meliputi sarana dan prasarana, kompetensi dan kreativitas guru, sumber belajar, metode serta dukungan lingkungan.

Wasliman (dalam Susanto 2013), juga menyatakan bahwa pencapaian 
hasil belajar siswa merupakan hasil interaksi baik faktor internal, maupun eksternal.

Faktor internal bersumber dari dalam diri siswa yang berpengaruh terhadap kemampuan belajar yang kecerdasan, minat dan perhatian, motivasi belajar, ketekunan, sikap, kebiasaan belajar, serta kondisi fisik dan kesehatan.

Faktor eksternal adalah faktor yang berasal dari luar yang mempengaruhi hasil belajar seperti keluarga, sekolah dan masyarakat. Keadaan keluarga berpengaruh terhadap hasil belajar siswa.

Dari penjelasan di atas dapat disimpulkan bahwa hasil belajar tidak hanya dipengaruhi oleh daya pikir dan kecerdasan siswa, namun juga dipengaruhi oleh faktor-faktor lain. Oleh sebab itu, guru sebagai peneliti harus mengetahui faktor-faktor yang mempengaruhi hasil belajar siswa, kemudian berupaya menanggulanginya melalui penggunaan model pembelajaran inovatif seperti PBL.

Trianto (2009) menyatakan PBL merupakan suatu model pembelajaran yang berdasarkan kepada junlah masalah yang membutuhkan penyidikan dan penyelesaian secara nyata.Ratumanan (dalam Trianto, 2009), mengungkapkan PBL adalah pendekatan yang efektif untuk melatih proses berpikir tingkat tinggi. Model ini mendukung siswa dalam melakukan proses informasi di dalam pikiran siswa kemudian menyusun pengetahuannya tentang dunia sosial dan sekitarnya. Peterson (dalam Amir, 2009) menyatakan bahwa tujuan utama dalam model pembelajaran PBL tidak hanya diperoleh pada saat pembelajaran sedang berlangsung namun juga diperoleh kecakapan hidup akibat dari proses pembelajaran tersebut.

Berdasarkan pemaparan di atas dapat diambil kesimpulan bahwa model pembelajaran Problem Based Learning (PBL) adalah model pembelajaran yang menggunakan permasalahan yang sering terjadi di dalam kehidupan sehari-hari untuk kemudian diselesaikan dengan menggunakan langkah-langkah tertentu.

Ciri-ciri PBL adalah pengajuan pertanyaan berupa masalah, fokus kepada keterkaitan antar disiplin, penyidikan autentik, membuat produk kemudian memamerkannya dan kerja sama. Model pembelajaran PBL mensituasikan pembelajaran ke dalam permasalahan yang sering terjadi dalam kehidupan sebagai pertanyaan yang penting untuk diselesaikan sehingga menciptakan suatu kebermaknaan bagi siswa. Permasalahan yang dibahas pada model pembelajaran PBL merupakan pemasalahan nyata sehingga siswa saat proses pemecahan masalah tersebut tidak hanya melihat dari satu sudut pandang yaitu bidang studi mateatika namun juga dari sudut pandang bidang studi lain.

Model pembelajaran Problem Based Instruction (PBL) mewajibkan siswa untuk melakukan penyelidikan autentik guna menemukan solusi nyata dari masalah nyata. Siswa harus menganalisis dan mendefinisikan permasalahan, mengembangkan hipotesis, dan merancang suatu ramalan, mengumpul dan menganalisis 
informasi, mengadakan eksperimen (jika diperlukan), menyusun inferensi, lalu membuat kesimpulan.

Model PBL menantang siswa agar menghasilkan suatu produk yang berupa karya dimana karya itu dapat mewakili penjelasaan dari penyelesaian permasalahan yang telah ditemukan.

Karakteristik dari model PBL adalah adanya kerja sama antara siswa dalam rangka menemukan cara penyelesaian masalah. Kerja sama akan dapat menimbulkan motivasi, pengembangan keterampilan sosial, dan juga keterampilan berpikir.

Tujuan dari model pembelajaran PBL adalah mendukung siswa dalam menumbuhkembangkan kemampuan berpikir dan kemampuan pemecahan masalah, belajar menjadi lebih dewasa dan autentik, serta menjadi siswa yang mandiri dan dapat bekerja sama dengan teman dalam menyelesaikan suatu permasalahan.

Sebelum melakukan proses pembelajaran dengan menggunakan PBL, guru sudah harus mempersiapakn segala perangkat yang diperlukan dalam pembelajaran. Adapun beberapa langkah pembelajaran PBL setelah dibentuk dalam kelompok belajar adalah siswa berusaha untuk memahami istilah dan konsep yang belum jelas, siswa merumuskan permasalahan, siswa menganalisis permasalahan kemudian menyusun ide penyelesaian masalah secara sistematis, merancang tujuan pembelajaran, mencari informasi dari sumberbelajar lain (diluar diskusi kelompok), sintesis (menggabungkan serta menguji) informasi baru dan menyusun laporan.
Arends (2013) mengungkapkan terdapat lima tahapan dalam model pembelajaran PBL yang penulis gunakan dalam penelitian ini. Tahap pertama adalah mengorganisasikan siswa pada permasalahan. Guru meninjau kembali tujuan pempelajaran serta memberikan motivasi kepada siswa agar turut serta pada kegiatan pemecahan masalah. Tahap kedua adalah menyiapkan siswa dalam belajar. Guru bersama siswa mendefenisikan serta menyusun tugas belajar yang berkaitan dengan permasalahan. Tahap ketiga adalah membantu siswa menjadi peneliti mandiri juga berkelompok. Guru mendukung siswa dalam mengadakan dan mengumpulkan informasi terkait, mengadakan uji coba serta menemukan cara penyelesaian serta solusinya. Tahap keempat adalah mengadakan pengembangan dan menyajikan hasil. Guru bersama siswa merencanakan dan menyusun hasil karya. Kemudian tahap terakhir adalah menganalisis dan mengevaluasi proses pemecahan masalah. Guru membantu siswa dalam merefleksikan hasil penyidikan mereka dan proses penyelesaian yang telah mereka gunakan.

Adapun tahapan-tahapan ataupun langkah-langkah pembelajaran pada model pembelajaran Problem Based Learning (PBL) yang digunakan pada penelitian ini yaitu: (1) orientasi siswa pada masalah, (2) mengorganisasikan siswa untuk belajar, (3) membimbing penyelidikan individu dan kelompok, (4) mengembangkan dan menyajikan hasil, dan (5) analisis dan evaluasi proses pemecahan masalah. 


\section{METODOLOGI PENELITIAN}

Peneliti memilih satu kelas untuk digunakan sebagai perwakilan dalam subyek penelitian. Peneliti memilih kelas III di 001 Rimba Sekampung sebagai subyek dari jumlah 3 kelas yang ada. Jumlah siswa tersebut adalah 20 siswa. Dengan jumlah lelaki 12 siswa dan 8 perempuan sebagai sampel dalam penelitian hasil belajar Matematika dengan menggunakan model pembelajaran PBL.
Peneliti memilih kelas tersebut karena dengan mempertimbangkan bahwa peneliti merupakan wali kelas tersebut dan hasil dari pra-tindakan masih banyak siswa yang belum tuntas dalam pembelajaran Matematika.

Penelitian Tindakan Kelas (PTK) dilakukan pada semester ganjil tahun pelajaran 2016/2017 selama 2 bulan. Mulai dari persiapan sampai dengan penulisan laporan hasil PTK waktu dirancang sebagaimana tabel berikut:

Tabel 1

Waktu Penelitian Tindakan Kelas

\begin{tabular}{clllllll}
\hline No & \multicolumn{1}{c}{ Jenis Kegiatan } & Agt & Sep & okt & Nov & Ket \\
\hline 1 & 1. & Perolehan kemampuan awal \\
& 2. & & & & & & \\
& $\begin{array}{l}\text { Menyusun instrumen dan } \\
\text { pembelajaran }\end{array}$ & skenario & $\checkmark$ & & & & \\
\hline 2 & $\begin{array}{l}\text { Pengumpulan data hasil : } \\
\text { 1. Siklus I }\end{array}$ & & & & & \\
& 2. Siklus II & & $\checkmark$ & $\checkmark$ & \\
\hline 3 & Penyusunan laporan hasil penelitian & & & \\
\hline
\end{tabular}

Penelitian Tindakan Kelas (PTK) ini akan dilaksanakan di SDN 001 Rimba Sekampung, Jl. Semangka, Kel Rimba Sekampung, Kec Dumai Kota. Lokasi tersebut adalah tempat peneliti mengajar.

Penelitian ini termasuk Penelitian Tindakan Kelas atau PTK. Penelitian tindakan ini diharapkan dapat memperbaiki proses pembelajaran yang telah dilakukan oleh guru. Penelitian Tindakan Kelas merupakan kegiatan yang berhubungan dengan tugas guru di lapangan. Kegiatan penelitian ini merupakan salah satu upaya guru untuk mengatasi masalah nyata yang ditemukan dalam melaksanakan tugas pembelajaran. Masalah tersebut benarbenar harus segera diatasi sedemikian sehingga peningkatkan mutu dan kualitas pembelajaran yang dilakukan guru dapat meningkat. Masalah yang segera diatasi dalam Penelitian Tindakan Kelas ini adalah rendahnya nilai hasil belajar matematika pada siswa kelas III SDN 001 Rimba Sekampung.

Rancangan penelitian PTK dapat dilakukan dalam beberapa siklus tergantung hasil lapangan. Satu siklus terdiri dari perencanaan (planning), tindakan (acting), observasi (observation), dan refleksi (reflection).

Dalam pelaksanaan PTK ini peneliti menggunakan model PTK kolaboratif yaitu peneliti berkolaborasi dengan seorang kolaborator yaitu wali kelas III dari kelas lainnya di SDN 001 
Rimba Sekampung. Adapun siklus spiral dari tahap-tahap penelitian tindakan kelas dapat dilihat pada gambar berikut ini:

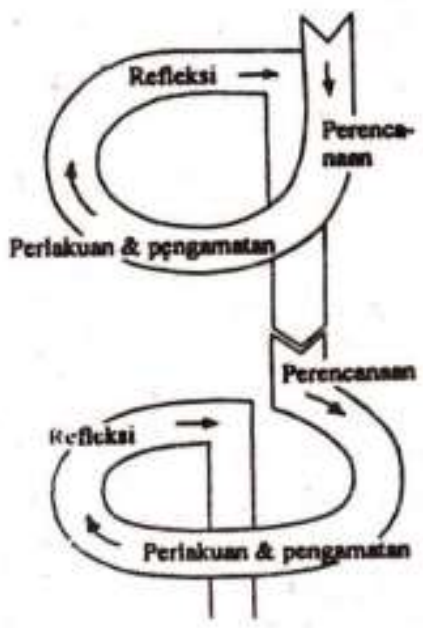

Gambar 1. Tahap-tahap dalam Penelitian Tindakan Kelas (PTK)

Perencanaan awal adalah penyusunan rumusan masalah, tujuan penelitian serta menyusun rencana tindakan serta instrumen penelitian dan perangkat pembelajaran.

Tindakan dan pengamatan, merupakan hal-hal yang dilakukan oleh peneliti sebagai upaya dalam meningkatkan hasil belajar siswa kemudian mengamati dampak dari implementasi model pembelajaran Problem Based Learning (PBL)

Refleksi adalah kajian mendalam oleh peneliti dengan cara melihat dan mempertimbangkan hasil serta dampak tindakan yang telah dilakukan.

Rancangan/rencana kemudian direvisi berdasarkan hasil refleksi dari siklus sebelumnya dengan cara menyusun perbaikan perencanaan yang dilaksanakan pada siklus berikutnya.

Sesuai dengan jenis penelitian, yaitu penelitian tindakan, maka penelitian ini menggunakan model penelitian tindakan kelas dari Kemmis dan Taggart (dalam Arikunto, 2010), yang berbentuk spiral dari siklus yang satu ke siklus berikutnya. Penelitian ini dilaksanakan dalam 2 siklus dimana setiap sikus terdiri atas 2 kali pertemuan dimana setiap siklus berdasarkan kepada materi dan tujuan pembelajaran sesuai dengan kurikulum, khususnya pada materi perkalian dan pembagian. Setiap siklus terdiri aas planning (rencana), action (tindakan), observation (pengamatan), dan reflection (refleksi). Langkah pada siklus berikutnya adalah perncanaan yang sudah direvisi, tindakan, pengamatan, dan refleksi.

Prosedur penelitian yang dilakukan oleh peneliti dalam memperbaiki kegiatan hasil belajar matematika dengan menggunakan model pembelajaran PBL terdiri atas prosedur penelitian Siklus I dan prosedur penelitian Siklus II dimana masing-masing prosedur terdiri atas perencanaan dan tindakan.

Tahap perencanaan ini digunakan peneliti untuk mempermudah kesiapan pada tahap pelaksana tindakan. Adapun persiapan dalam penelitian ini adalah: (1) melakukan observasi pembelajaran siswa di kelas III guna memperoleh gambaran mengenai kegiatan pembelajaran, karakteristik siswa serta mengambil data awal siswa; (2) menyusun rencana dan waktu penelitian; (3) mengkaji standar kompetensi, kompetens dasar dan materi pokok dan juga menyusun perangkat pembelajaran yang terdiri dari silabus, RPP, LKS, Soal evaluasi 
siswa kunci jawaban dan instrumen penelitian; dan (4) menyiapkan media yang digunakan dalam kegiatan pembelajaran pada siklus I

Pada tahap pelaksanaan tindakan Siklus I, peneliti menyusun skenario perencanaan pembelajaran atau RPP agar tindakan dalam penelitian dapat berlangsung dengan baik dan tersusun sesuai dengan kronologis. Selama proses pelaksanaan pembelajaran berlangsung peneliti menggunakan model pembelajaran PBL. Sementara itu teman sejawat yang sebagai kolaborator akan mengamati partisipasi dan aktivitas belajar siswa pada saat proses pembelajaran. Pertemuan pertama pada siklus I membahas tentang mengkonversikan satuan jarak.

Pada tahap pengamatan, peneliti mengamati, merekam dan mencatat semua aktivitas siswa selama proses belajar mengajar berlangsung. Berdasarkan pengamatan dilakukan secara bersamaan dengan menggunakan lembar pengamatan siswa, karena antara tindakan dan observasi merupakan suatu kesatuan. Hasil yang diperoleh dari observasi ini akan memberikan petunjuk perbaikan untuk pemberian tindakan selanjutnya. Melalui observasi ini peneliti dapat mengetahui sejauh mana mode pembelajaran PBL dapat diterapkan.

Pengamatan dilakukan oleh kolaborator / teman sejawat yang memahami tentang pembelajaran matematika. Adapun tugas kolaborator adalah sebagai berikut: (1) menilai proses proses pembelajaran yang dilakukan oleh guru dengan menggunakan instrumen yang telah disusun; (2) mengamati siswa dan melakukan penelitian hasil belajar matematika dengan menggunakan model pembelajaran PBL; dan (3) mengamati keaktifan siswa dalam proses pembelajaran.

Refleksi merupakan hasil dari pengamatan dan catatan-catatan hasil evaluasi dalam proses penelitian dan menjadi dasar penyusunan rencana tindakan pada pertemuan berikutnya agar dapat berjalan lancar dan memperoleh peningkatan hasil lebih baik dari pertemuan selanjutnya atau pada siklus ke II.

Prosedur penelitian pada siklus II diawali dengan tahap perencanaan. Sebelum penelitian dilakukan terlebih dahulu peneliti melakukan perencanaan. Dalam tahap perencanaan, peneliti melakukan beberapa kegiatan seperti mencari referensi yang berkaitan dengan langkah-langkah Penelitian Tindakan Kelas dan bagaimana penyusunannya, bersama dengan guru sebagai kolaborator, peneliti mendiskusikan tujuan penelitian, dan mengkaji materi matematika kelas II yang berkenaan dengan perkalian dan pembagian. Peneliti merencanakan skenario pembelajaran dan juga menyiapkan fasilitas pendukung untuk melaksanakan skenario tindakan tersebut.

Tahap berikutnya adalah melakukan tindakan siklus II dengan melaksanakan pembelajaran dengan menggunakan model PBL.

Pada tahap pengamatan, peneliti mengamati, merekam dan mencatat semua aktivitas siswa selama proses 
belajar mengajar berlangsung.

Berdasarkan pengamatan dilakukan secara bersamaan dengan menggunakan lembar pengamatan siswa, karena antara tindakan dan observasi merupakan suatu kesatuan. Hasil yang diperoleh dari observasi ini akan memberikan petunjuk perbaikan untuk pemberian tindakan selanjutnya. Melalui observasi ini peneliti dapat mengetahui sejauh mana model pembelajaran PBL dapat diterapkan.

Pengamatan dilakukan oleh kolaborator / teman sejawat yang memahami tentang pembelajaran matematika.

Refleksi merupakan hasil dari pengamatan dan catatan-catatan hasil evaluasi dalam proses penelitian dan menjadi dasar penyusunan rencana tindakan pada pertemuan berikutnya agar dapat berjalan lancar dan memperoleh peningkatan hasil lebih baik untuk penelitian berikutnya.

Teknik pengumpulan data dalam penelitian ini ditempuh dengan dua cara, yaitu menggunakan teknik tes dan non tes. Teknik non tes dilakukan dengan menggunakan observasi, sedangkan tes dilakukan dengan memberikan soal evaluasi kepada siswa. Pengumpulan data yang akan digunakan dalam penelitian ini terdiri atas tes evaluasi belajar siswa, pengamatan (observasi) dan dokumentasi.

Teknik analisis data digunakan peneliti untuk mengolah data hasil penelitian dengan tujuan agar data mudah dibaca dan dipahami oleh peneliti maupun orang lain yang membaca hasil penelitian. Tehnik analisis data yang digunakan peneliti adalah teknik analisis data kuantitatif Data yang diperoleh peneliti melalui tes tertulis objektif maupun uraian berupa nilai belajar siswa selanjutnya akan dianalisis oleh peneliti dengan teknik analisis data kuantitatif. Analisis data kuantitatif dilakukan dengan menghitung nilai rata-rata siswa. Analisis data kauntitatif ini dilaksanakan setiap akhir dari satu siklus. Dengan demikian, analisis data kuantitatif akan menjadi refleksi pada siklus selanjutnya. Setelah menghitung jumlah dan rata-rata siswa, lanhkah selanjutnya adalah menghitung persentase siswa yang telah mencapai KKM (Kriteria Ketuntasan Minimal).

\section{HASIL DAN PEMBAHASAN}

Sajian data hasil penelitian tindakan kelas yang telah dilaksanakan menggunakan model pembelajaran pada siklus I dan II yaitu model pembelajaran Problem Based Learning (PBL) Dalam penyajian data akan dibahas berdasarkan urutan siklus yang telah dilaksanakan, yaitu siklus I dan siklus II. Setiap siklus dilaksanakan pada 2 kali pertemuan, jadi total dari siklus I dan II adalah 4 kali pertemuan dengan materi mengenai perkalian dan pembagian pada siswa kelas III.

Untuk hasil belajar siswa agar memudahkan dalam pembahasan dan mengetahui perkembangan hasil belajar, maka data disajikan secara global dalam kemampuan guru. Hasil belajar siswa akan disajikan dari data awal, siklus I dan siklus II dengan data sebagai berikut: 
Tabel 2.

Hasil Belajar Siswa

\begin{tabular}{|c|c|c|c|c|c|c|c|c|c|c|}
\hline \multirow{2}{*}{ To } & \multirow{2}{*}{$\begin{array}{c}\text { Rent } \\
\text { ang } \\
\text { Nilai }\end{array}$} & \multicolumn{3}{|c|}{ Jumlah Siswa } & \multicolumn{3}{|c|}{ Rata-Rata (\%) } & \multicolumn{3}{|c|}{ Rata-rata Nilai } \\
\hline & & Awal & $\begin{array}{c}\text { Siklus } \\
\text { I }\end{array}$ & $\begin{array}{c}\text { Siklus } \\
\text { II }\end{array}$ & Awal & $\begin{array}{c}\text { Siklus } \\
\text { I }\end{array}$ & $\begin{array}{c}\text { Siklus } \\
\text { II }\end{array}$ & Awal & $\begin{array}{c}\text { Siklus } \\
\text { I }\end{array}$ & $\begin{array}{c}\text { Siklus } \\
\text { II }\end{array}$ \\
\hline 1 & $>70$ & 13 & 15 & 17 & $66,7 \%$ & $71,43 \%$ & $80,95 \%$ & & & \\
\hline 2 & $<70$ & 7 & 6 & 4 & $33,3 \%$ & $28,57 \%$ & $19,05 \%$ & 76,2 & 80 & 83,3 \\
\hline
\end{tabular}

Dari tabel di atas terlihat bahwa peningkatan hasil belajar siswa dalam pembelajaran matematika menggunakan model pembelajaran Problem Based Learning (PBL) mengalami peningkatan yang signifikan. Dari jumlah siswa yang tuntas pada data awal adalah 13 orang siswa atau dengan persentase $61,90 \%$ mengalami peningkatan pada siklus I yaitu 15 orang siswa dengan persentase $71,43 \%$ selanjutnya pada siklus II mengalami peningkatan lagi menjadi 17 orang siswa atau dengan persentase $80,95 \%$. Jumlah siswa yang tidak tuntas atau dibawah $<70$ mengalami penurunan dari data awal 7 orang siswa atau $33,34 \%$ mengalami penurunan pada siklus I menjadi 6 orang siswa atau dengan persentase $28,57 \%$ dan pada siklus II mengalami penurunan kembali menjadi 4 orang siswa atau dengan persentase $19,05 \%$.

Selanjutnya dari tabel juga terlihat rata-rata akhir penilaian pembelajaran mengalami peningkatan. Dari data awal terlihat hasil belajar siswa mendapatkan rata-rata nilai sebesar 76,2 mengalami peingkatan pada siklus I menjadi 80 dan pada siklus II mengalami peningkatan sebesar 3,30 poin atau menjadi 83,30 .
Dari hasil evaluasi belajar pada siklus II dengan rata-rata 82,20 atau persentase ketuntasannya adalah $75 \%$ sudah mencukupi dari minimal hasil klasikal yaitu $75 \%$ maka penelitian ini hentikan pada siklus II dan akan dilanjutkan apabila ada penelitian berikutnya.

Grafik hasil belajar siswa disajikan pada gambar berikut:

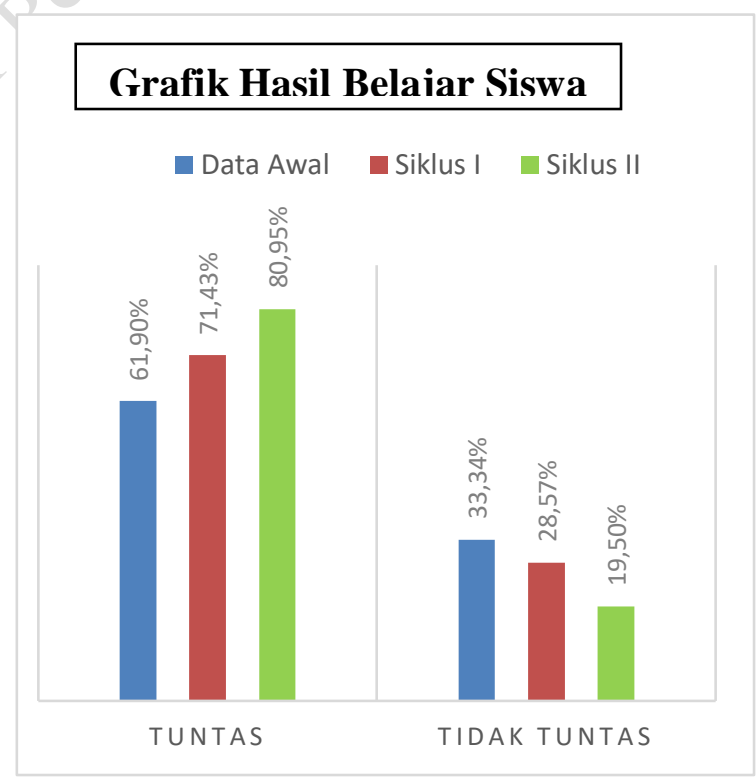

Gambar 2. Grafik Hasil Belajar Siswa

Melalui grafik diatas terlihat jelas hasil belajar siswa dalam pembelajaran matematika dengan menggunakan model pembelajaran Problem Based Learning (PBL) dapat meningkatkan dan memperbaiki hasil belajar 
matematika pada siswa kelas III SDN 001 Rimba Sekampung. Terlihat jelas jumlah siswa yang tuntas pada data awal yaitu $61,90 \%$ naik menjadi $71,43 \%$ dan pada siklus II semakin meningkat menjadi $80,95 \%$ siswa yang tuntas pembelajaran. Selanjutnya untuk siswa yang tidak tuntas mengalami penurunan dari data awal mendapatkan persentase $33,34 \%$ menjadi $28,57 \%$ dan semakin mengalami penurunan pada siklus II menjadi 19,05\%.

Dari hasil penelitian di atas dapat dilihat terjadi peningkatan prestasi belajar siswa yang ditandai dengan naiknya nilai rata-rata tes siswa dan ketuntasan belajar siswa. Dengan demikian, hasil penelitian di atas membuktikan hipotesis bahwa penggunaan model pembelajaran Problem Based Learning (PBL) dapat meningkatkan prestasi belajar dalam mata pelajaran matematika. Selain itu model pembelajaran Problem Based Learning (PBL) dapat memberikan suasana belajar baru dan dapat membantu memotivasi belajar siswa dalam belajar sehinga prestasi belajar mereka dapat meningkat maka tidak perlu melanjutkan pada siklus berikutnya.

Kesimpulan dari pengamatan (observation) terhadap guru pada siklus I untuk pertemua pertaman dan kedua hasilnya meningkat dari skor 75 atau mendapat skor "baik" menjadi 82,50 atau mendapat skor "baik". Dalam hal ini pengamatan terhadap guru sudah bagus hanya saja untuk beberapa hal dapat diperbaiki pada siklus selanjutnya agar proses pembelajaran dapat berlangsung dengan baik dan lancar.

Kesimpulan dari pengamatan (observation) terhadap guru pada siklus II untuk pertemuan pertama dan kedua hasilnya meningkat dari skor 87,50 atau mendapat skor "sangat baik" menjadi 92,50 atau mendapat skor "baik". Dalam hal ini pengamatan terhadap guru sudah bagus dan pada siklus selanjutnya dapat dipertahankan agar proses pembelajaran dapat berlangsung dengan baik dan lancar.

Dari hasil observasi terhadap guru yang telah diamati oleh kolaborator meningkat dari siklus I yaitu 82,50 atau kategori "baik" mengalami peningkatan menjadi 92,50 atau kategori "sangat baik" pada siklus II. Jadi hasil pengamatan atau observasi dalam proses pembelajaran pada siklus II dihentikan karena sudah mencapai hasil yang diinginkan dalam penelitian sehingga proses pembelajaran dianggap sudah termasuk kedalam kategori sangat baik.

\section{SIMPULAN DAN SARAN}

Berdasarkan hasil penelitian dan pembahasan, dapat disimpulkan bahwa dengan menggunakan model pembelajaran Problem Based Learning (PBL) dalam pembelajaran matematika pada perkalian dan pembagian dapat meningkatkan hasil belajar pada siswa kelas III SDN 001 Rimba Sekampung ini terlaksana melalui dua siklus yaitu siklus I dan siklus II. Masing-masing siklus terdiri dari dua kali pertemuan.

Peningkatan hasil belajar siswa ditunjukkan dengan adanya perubahan nilai pada pra tindakan, yaitu sebelum 
terjadi proses pembelajaran, di mana pada awalnya siswa merasa pembelajaran terlalu menonton dan hanya berfokus pada materi buku cetak saja, tetapi setelah melaksanakan diskusi dengan model pembelajaran Problem Based Learning (PBL) siswa lebih bersemangat untuk mencari jawaban dengan kemampuannya sendiri dan kelompoknya.

Hasil pengamatan terhadap guru pada siklus II untuk pertemuan pertama dan kedua hasilnya meningkat dari skor 87,50 atau mendapat skor "sangat baik" menjadi 92,50 atau mendapat skor 'baik".

Dengan demikian hasil pengamatan, dari kegiatan pertama sampai akhir pembelajaran dengan menggunakan model pembelajaran Problem Based Learning (PBL) semakin meningkat. Keberhasilan penggunaan model pembelajaran Problem Based Learning (PBL) juga dibuktikan dengan meningkatnya nilai hasil belajar baik dilihat dari nilai ratarata tes maupun persentase ketuntasan belajar siswa dari pra tindakan, akhir siklus I dan hasil akhir siklus II. Sebelum dilakukannya tindakan, nilai rata-rata siswa hanya mencapai 76,2 dengan persentase ketuntasan siswa $61,90 \%$ atau sebanyak 7 siswa yang belum tuntas dari 21 siswa. Pada siklus I diperoleh nilai rata-rata siswa mencapai 80 dengan persentase ketuntasan siswa $71,43 \%$ atau sebanyak 6 siswa yang belum tuntas dari 21 siswa.

Pada siklus II diperoleh nilai ratarata siswa sebesar 83,30 dengan persentase ketuntasan siswa 80,95\% atau sebanyak 4 siswa yang belum tuntas dari 21 siswa. Hal tesebut menunjukkan bahwa pembelajaran dengan menggunakan metode Problem Based Learning (PBL) sudah terlaksana dengan baik sesuai dengan yang diharapkan dan mengalami peningkatan.

Penggunaan model pembelajaran Problem Based Learning (PBL) sebaiknya digunakan oleh guru dalam mengajarkan mata pelajaran yang membutuhkan siswa untuk berpikir secara rasional, khusunya dalam pembelajaran matematika

Dalam menanamkan konsep pembelajaran sebaiknya guru lebih menggunakan teknik dan metode belajar baru yang telah dikembangkan oleh ahli pendidikan yang lebih baik dan banyak mafaatnya karena jika hanya mengajar menggunakan metode ceramah, siswa akan cepat merasa bosan.

\section{DAFTAR PUSTAKA}

Amir, M. T. (2009). Inovasi Pendidikan Melalui Problem Based Learning. Jakarta: Kencana.

Arends, R.I. (2013). Belajar untuk mengajar. Learning to teach. Edisi 9. Jakarta: Salemba Humanika.

Arikunto, S. (2010). Prosedur Penelitian Suatu Pendekatan Praktik. Jakarta: Rineka Cipta.

Majid, A. (2014). Belajar dan Pembelajaran. Bandung: PT Rosdakarya.

Nasution, E. Y. P., \& Lubis, F. H. (2019). Meningkatkan Aktivitas 
dan Hasil Belajar Siswa melalui Model Pembelajaran Kooperatif Tipe Jigsaw Berbasis Algebrator. Pythagoras: Jurnal Program Studi Pendidikan Matematika, 8(2), 82-92.

Nasution, E. Y. P., Gunawan, R. G., \& Yulia, P. (2019). Pengaruh Model Pembelajaran Problem Based Instruction (PBI) terhadap Kemampuan Penalaran Matematis Siswa. Logaritma: Jurnal Ilmu-ilmu Pendidikan dan Sains, 7(02), 163-176.

Rahmi, H., Saputra, J., Desriati, W., \& Fatmawati, F. (2020). Peningkatan Kemampuan Berhitung Siswa Kelas II Dengan Menggunakan Sempoa Aritmatika Di Sekolah Dasar. Madani: Indonesian Journal of Civil Society, 2(2), 50-56.

Rahmi, H., Zamista, A. A., \& Saputra, J. (2019). Pelatihan Penelitian Tindakan Kelas Kepada Guru SDN 001 Rimba Sekampung Dumai. Madani: Indonesian Journal of Civil Society, 1(1), 2933.

Rusmono. 2012. Strategi Pembelajaran dengan Problem Based Learning itu Perlu. Bogor: Ghalia Indonesia.

Siregar, N. F., \& Nasution, E. Y. P. (2019). Pembelajaran Matematika Berbasis Higher Order Thinking Skills. In Curup Annual Conference on Math (CACM) (Vol. 1, No. 1, pp. 2126).

Susanto, A. (2013). Teori Belajar dan Pembelajaran di Sekolah
Dasar. Jakarta: Penanda Media Group.

Trianto (2009). Mendesain Model Pembelajaran InovatifProgresif. Jakarta: Kencana Prenada Media Group. 